\title{
Making Sense of Smart Living, Working, and Organizing Enhanced by Supposedly Smart Objects and Systems
}

\author{
Steven Alter \\ ${ }^{1}$ University of San Francisco, Sa Francisco 94117, USA \\ alter@usfca.edu
}

\begin{abstract}
The term smart is applied to many different types of things in today's world, leaving the question of what is meant by the title of an IFIP 8.6 workshop called "Smart Living, Working, and Organizing." This paper's goal is to provide a conceptual basis for making sense of "smart living, working, and organizing." It provides many examples of nominally smart objects and systems, presents principles related to smartness, provides a definition of smart that applies to objects and systems, presents dimensions related to four categories of smartness, and uses two brief examples to show how those dimensions might be used in thinking about how to make an object or system smarter.
\end{abstract}

Keywords: Smart living, Smart working, Smart organizing, Smart object, Smart system, Definition of Smart 


\section{Is a Hospital Smart if Its Nurses Use Smart Thermometers?}

This paper responds to the Call for Papers for the IFIP 8.6 workshop on Smart Living, Working, and Organizing by trying to make sense of the term smart in the context of living, working, and organizing.

An elusive idea. The idea of "Smart Living, Working, and Organizing" is suggestive but elusive. The CFP does not define smart, but mentions smart devices, smart homes, smart cars, smart phones, smart government, smart cities and smart organizations. Wikipedia contains articles about many other supposedly smart things, such as smart bombs, smart bullets, smart cameras, smart cards, smart clothing, smart contracts, smart doorbells, smart drinks, smart fabrics, smart farming, smart file systems, smart fluids, smart glass, smart glasses, smart grids, smart guns, smart highways, smart keys, smart labels, smart lighting, smart locks, smart manufacturing, smart materials, smart meters, smart mirrors, smart missiles, smart numbers, smart objects, smart pensions, smart power, smart speakers, smart systems, smart terminals, smart watches, and smart whiteboards. Microsoft Word 2016 touts nominally smart capabilities including smart quotes, smart lookup, smart copy and paste, smart paragraph selection, and smart cursoring. While writing this paper, I learned about competition in the world of smart toothbrushes, one version of which identifies whether specific teeth have been cleaned and transmits that information to a smart phone where it is displayed superimposed on an image of a set of teeth. The decades-old stream of research and practice related to artificial intelligence, computer science, statistics, and other fields brings concepts, methods, experience, and a great deal of techno-hype and salesmanship related to subjects such as machine learning, big data, Internet of things, and recently, cognitive computing.

The diverse nature of those supposedly smart things illustrates why it is difficult to say something nontrivial about smartness that fits most of those examples and that helps in understanding smart living, working, and organizing. The diversity of supposedly smart things and capabilities leads to doubting whether their supposed smartness implies they have common properties. Viewed more broadly, one might wonder whether it would be fruitful, or even possible to theorize or generalize about the nature or impacts of smartness if the same concept purports to describe smart toothbrushes, smart bombs, and smart cities. Furthermore, a definition of smart that emphasizes the presence of artificial intelligence, big data, or cognitive computing would automatically disqualify many supposedly smart objects or systems that do not use those approaches.

Goal and organization. This research essay tries to provide a conceptual basis for making sense of "smart living, working, and organizing." Making sense of smartness in that context is necessary if discussions of that topic are to move beyond scattered predictions, social criticism, and/or philosophizing based on whatever examples seem interesting or potentially profitable to whomever is writing or speaking.

The goal: Characterize smart and smartness in relation to objects and systems in a way that is useful for describing, analyzing, and designing objects and systems. 
The next section identifies principles that can be applied in thinking about the concept of smartness as it might apply to smart living, working, and organizing. The principles are capability-orientation, context-dependence, multidimensionality, separability, and applicability to objects, automated systems, and sociotechnical systems. The principles lead to a definition of smartness in the context of objects and systems. The definition leads to a classification matrix for smart capabilities, which fall into four areas, information processing, internal regulation, action in the world, and knowledge acquisition. Each of those areas includes a set of capabilities that can be described on a continuum from not smart to somewhat smart to extremely smart based on the definition of smart. A concluding section describes how this multidimensional view of smartness can be applied in thinking about smartness while describing, analyzing, and designing objects and systems. Except for a brief comment near the end, this paper focuses almost entirely on understanding what smart might mean in the context of living, working, and organizing. It does not cover important topics concerning conflicting stakeholder interests such as privacy, autonomy, job satisfaction, equity, and wealth.

What about adoption of technology? Adoption and diffusion of technology is the traditional focus of IFIP WG 8.6. This paper's focus on defining smartness and dimensions of smartness is directly related to adoption and diffusion of smart technologies because is not meaningful to theorize or generalize about adoption and diffusion of smart things unless the concepts of smart and smartness are taken seriously. That requires defining those terms and not just treating smart and smartness essentially as hype that serves as little more than enticement.

\section{Principles Related to Smart and Smartness}

This paper's view of smart and smartness is related to purposefully constructed entities including objects, sociotechnical systems, and totally automated systems. It explicitly excludes consideration of smart or smartness as a characteristic of human intellect, of groups of people, or of natural capabilities of living things. It assumes that applications of AI methods and research may or may not be related to smartness in the sense of smart living, working, and organizing.

While most significant aspects of living, working, and organizing occur within sociotechnical systems, this paper assumes that the concept of smartness must have a broader domain that includes objects and totally automated systems. That is necessary because a current sociotechnical system that happens to use objects that are currently viewed as smart may evolve into a more automated system that relies on smart objects and other systems in ways not yet imagined. The discussion of smartness needs to cover those cases, but a focus on smart living, working, and organizing calls for special emphasis on sociotechnical systems in which nominally smart technologies are used. For example, it includes uses of smart phones within sociotechnical systems that perform systematic sales work or systematic customer service work. It might include the use of smart phones to make phone calls if communication in a general sense is 
viewed as a sociotechnical system. It pays little attention to uses of smart phones for playing single player games while riding a bus because that type of individual activity generally is not associated with research or practice related to sociotechnical systems.

This paper's consideration of smartness in the context of sociotechnical systems is guided by the following principles, which coalesced as this paper was being written (i.e., did not come from a literature survey). The principles are introduced at this point in the paper to make it easier to understand how this paper's ideas unfold

Capability-orientation. An entity's smartness is described in terms of its capabilities for performing types of actions that are associated with smartness. Thus, a sociotechnical system's smartness along the various dimensions of smartness can be assessed by observing how it operates.

Context-dependence. An entity that might seem smart along some of the dimensions of smartness within a context might be totally unsmart on those dimensions in another context. For example, a sociotechnical system that seems to be smart in the context of dealing with minor variations in a highly repetitive situation might be unable to function in the presence of high variation.

Multidimensionality. Smartness is not a binary, yes/no distinction. Smartness can be viewed as a set of continuous variables or dimensions that individually range from not at all smart to extremely smart. The dimensions are assumed to be only partially independent, i.e. that smartness on one dimension often is partially dependent on smartness along another dimension. While it is always possible to combine any set of numerical dimensions into a single numerical score (e.g., the average of numerical scores for 10 dimensions), there is little reason to believe that a combined smartness score is useful for describing or comparing entities with regard to smartness.

Separability. An entity that includes or uses a nominally smart component may not be smart of its own right. For example, a hospital that uses smart thermometers may not be smart in terms of most or all of the dimensions of smartness. Similarly, having an exceptionally smart exhaust system does not imply that an entire car should be viewed as smart.

Applicability to objects, totally automated systems, and sociotechnical systems. Totally automated systems are increasingly evident as subsystems of sociotechnical systems. The dimensions of smartness should make sense for objects, totally automated systems, and sociotechnical systems.

\section{Definition of Smart}

This section defines smart and related dimensions of smartness in a way that applies both to objects and to sociotechnical systems in which smart living, working, and organizing occur. The powerful trend toward automating important parts of business operations calls for using a definition and set of dimensions that apply beyond just sociotechnical systems. As automation possibilities continue to appear, there will be many situations in which it may not be obvious whether a smartness initiative should be directed at an entire sociotechnical system or at specific components. The definition of smart and the dimensions of smartness should apply in either case. 


\subsection{Smart in the Context of Living, Working, and Organizing}

The introduction mentioned the difficulty of trying to define smart in a way that applies in a nontrivial way to most of supposedly smart things that it mentions. Searches of Google Scholar for various "smart" things (e.g., smart phones, smart cities, etc.) did not come close to producing a consensus definition that is useful here.

A hint at a possible direction for thinking about the topic of "smart living, working, and organizing," comes from [1], a 2015 editorial in the journal Service Science. That editorial defines smart service system as follows:

"a system capable of learning, dynamic adaptation, and decision making based upon data received, transmitted, and/or processed to improve its response to a future situation. The system does so through self-detection, self-diagnosing, selfcorrecting, self-monitoring, self-organizing, self-replicating, or self-controlled functions. These capabilities are the result of the incorporation of technologies for sensing, actuation, coordination, communication, control, etc."

Most of the nominally smart things mentioned in this paper's introduction exhibit aspects of some of those capabilities. Combining those ideas with the general spirit of the five principles mentioned earlier, smartness calls for at least some automated information processing and at least some degree of self-control, learning, adaptation, and/or decision-making related to performing activities or functions that have consequence in the world.

Definition of smartness. Purposefully designed entity $X$ is smart to the extent to which it performs and controls functions that produce directly perceptible results for people by using automated capabilities for processing information, interpreting information, and/or learning from information that may or may not be specified by its designers.

Specific aspects of the definition should be noted:

"Purposefully designed entity." The entities under consideration are designed. They are artificial [2]. They may have evolved through many iterations that involve at least some degree of conscious design effort, either through formal projects with allocated resources or through workarounds and adaptations to overcome limitations of previously existing versions of object or system.

"Smart to the extent to which." Smartness is not a binary, yes/no variable that describes whether something is or is not smart. Instead, smartness is a continuous variable or a series of continuous variables related to different aspects of smartness.

"Performs and controls functions that produce directly perceptible results for people." This phrase is stated in a way that applies to both objects and sociotechnical systems. Specifying that the functions performed and/or controlled produce directly perceptible results for people implies greater concern about things that people can perceive and less concern for about automated activity deep within computing infra- 
structures that only technicians perceive. Notice that the visibility of a function does not imply that it is the most important aspect of a situation. Consistent with the principle of separability,a smart attendance system in an automobile factory would not be evidence that the factory is smart because the factory's primary functions are related to producing automobiles, not taking attendance.

"Automated capabilities for processing information." The primary components of purely social systems and noncomputerized work systems do not perform automated information processing and therefore cannot be smart in this sense. Processing information can be subdivided into capturing, storing, retrieving, transmitting, manipulating, and/or displaying information, each of which will be treated as a dimension of smartness within the category of processing information.

"Automated capabilities for interpreting information." This includes drawing conclusions from information, such as recognizing the semantics of the information and evaluating the extent to which the information is correct.

"Learning from information that may or may not be specified by its designers." This includes executing predefined scripts and capturing or creating new knowledge and internalizing that knowledge into the nominally smart entity itself.

Such careful attention to the definition of smartness might seem excessive, but actually is important for serious discussion of smart systems and devices Aside from the general benefits of defining terms, serious attention to the definition of smartness helps in separating the discourse of smart systems and devices from common uses the term smart related to whether or not people are smart and whether or not an object or system's design has convenient or otherwise beneficial features. Smart systems and devices are products of human intellect but are not a direct reflection of the intellect of any individual or group. Smartness also is not treated as a synonym of high quality, good fit to needs, or otherwise impressive or beneficial capabilities. Mixing those three views of smartness leads to confusion. A product/service that exhibits excellent quality and fits customer requirements in an extremely clever way might not exhibit smartness as defined here. Conversely, a product/service might have low quality or inadequate fit to user needs even though it exhibits some of the characteristics of smartness as defined here.

\section{Classification Matrix for Smart Capabilities}

Defining smartness is a step forward, but the definition provides little guidance for supporting description, analysis, and design of smart objects and systems. The next step is a classification matrix shown below Table 1, which includes a very brief description of each capability. The horizontal categories are basically different domains of smartness, i.e., smartness related to information processing, internal regulation, action in the world beyond the object or system, and knowledge acquisition. The second, third, and fourth domains rely on the first domain, but are different enough to identify separately. It is possible for an object or system to be very smart in one or several of these domains, but not smart at all in others. For example, an ability to capture information through sensors does not imply that an object or system can use 
that information for internal regulation, for action in the world beyond itself, or for accumulating knowledge.

Table 1. Classification matrix for smart capabilities

\begin{tabular}{|c|c|c|c|c|}
\hline & $\begin{array}{c}\text { Information } \\
\text { processing }\end{array}$ & $\begin{array}{c}\text { Internal regu- } \\
\text { lation }\end{array}$ & $\begin{array}{c}\text { Action in the } \\
\text { world }\end{array}$ & $\begin{array}{l}\text { Knowledge ac- } \\
\text { quisition }\end{array}$ \\
\hline $\begin{array}{l}\text { Scripted } \\
\text { execution }\end{array}$ & $\begin{array}{l}\text { Execution of } \\
\text { prespecified } \\
\text { instructions in a } \\
\text { computer pro- } \\
\text { gram }\end{array}$ & $\begin{array}{l}\text { Internal regula- } \\
\text { tion based on a } \\
\text { prespecified } \\
\text { script or method }\end{array}$ & $\begin{array}{l}\text { Visible action } \\
\text { based on a pre- } \\
\text { specified script or } \\
\text { method }\end{array}$ & $\begin{array}{l}\text { Acquisition and } \\
\text { internalization of } \\
\text { information based } \\
\text { on a prespecified } \\
\text { script or method }\end{array}$ \\
\hline $\begin{array}{l}\text { Formulaic } \\
\text { adaptation }\end{array}$ & $\begin{array}{l}\text { Adaptation of } \\
\text { information } \\
\text { processing based } \\
\text { on prespecified } \\
\text { inputs or condi- } \\
\text { tions }\end{array}$ & $\begin{array}{l}\text { Adaptation of } \\
\text { internal regula- } \\
\text { tion based on } \\
\text { prespecified } \\
\text { inputs or condi- } \\
\text { tions }\end{array}$ & $\begin{array}{l}\text { Adaptation of } \\
\text { current action in } \\
\text { the world based } \\
\text { on prespecified } \\
\text { inputs or condi- } \\
\text { tions }\end{array}$ & $\begin{array}{l}\text { Adaptation of } \\
\text { knowledge acqui- } \\
\text { sition based on } \\
\text { prespecified } \\
\text { inputs or condi- } \\
\text { tions }\end{array}$ \\
\hline $\begin{array}{l}\text { Creative } \\
\text { adaptation }\end{array}$ & $\begin{array}{l}\text { Adaptation of } \\
\text { information } \\
\text { processing in- } \\
\text { structions based } \\
\text { on unscripted or } \\
\text { partially scripted } \\
\text { analysis of rele- } \\
\text { vant information } \\
\text { or conditions }\end{array}$ & $\begin{array}{l}\text { Adaptation of a } \\
\text { script for inter- } \\
\text { nal regulation } \\
\text { based on un- } \\
\text { scripted or par- } \\
\text { tially scripted } \\
\text { analysis of rele- } \\
\text { vant information } \\
\text { or conditions }\end{array}$ & $\begin{array}{l}\text { Adaptation of a } \\
\text { script for action } \\
\text { in the world } \\
\text { based on un- } \\
\text { scripted or par- } \\
\text { tially scripted } \\
\text { analysis of rele- } \\
\text { vant information } \\
\text { or conditions }\end{array}$ & $\begin{array}{l}\text { Adaptation of a } \\
\text { script for } \\
\text { knowledge acqui- } \\
\text { sition based on } \\
\text { unscripted or } \\
\text { partially scripted } \\
\text { analysis of rele- } \\
\text { vant information } \\
\text { or conditions }\end{array}$ \\
\hline $\begin{array}{l}\text { Unscripted } \\
\text { or partial- } \\
\text { ly scripted } \\
\text { invention }\end{array}$ & $\begin{array}{l}\text { Unscripted or } \\
\text { partially scripted } \\
\text { design and exe- } \\
\text { cution of a work- } \\
\text { around or new } \\
\text { method for pro- } \\
\text { cessing infor- } \\
\text { mation }\end{array}$ & $\begin{array}{l}\text { Unscripted or } \\
\text { partially scripted } \\
\text { design and exe- } \\
\text { cution of a } \\
\text { workaround or } \\
\text { new method for } \\
\text { internal regula- } \\
\text { tion }\end{array}$ & $\begin{array}{l}\text { Unscripted or } \\
\text { partially scripted } \\
\text { design and execu- } \\
\text { tion of a worka- } \\
\text { round or new } \\
\text { method related to } \\
\text { action in the } \\
\text { world }\end{array}$ & $\begin{array}{l}\text { Unscripted or } \\
\text { partially scripted } \\
\text { planning and } \\
\text { execution of a } \\
\text { workaround or } \\
\text { new method } \\
\text { related to } \\
\text { knowledge acqui- } \\
\text { sition }\end{array}$ \\
\hline
\end{tabular}

The rows in Table 1 go from scripted execution of prespecified instructions through formulaic adaptation, creative adaptation, and finally, unscripted or partially scripted invention. Effective sociotechnical systems generally have capabilities in every cell of the matrix, and usually have possibilities for improvement in some of those areas. Things that are called smart objects often have capabilities in only one or several of those areas. Scripted execution, i.e., following programmed instructions, is fundamental to all computing and generally describes sociotechnical systems whose processes are highly structured and mechanical. Formulaic adaptation is common, as in the handling of repetitive exceptions within organizational routines. Creative adaptation is more challenging due to novelty and difficulty of changing established practices. It becomes especially challenging when it involves abstraction, inference, optimization, or search to develop a new adaptation that was not specified in advance. Unscripted or partially scripted invention involves producing new understandings, 
methods, or artifacts using inferences or extrapolations from past, current, or projected future situations. Many sociotechnical systems perform localized invention through workarounds or other unscripted or partially scripted responses to conditions that make it difficult to fulfill organizational or personal goals (e.g., see theory of workarounds [3]). Totally automated invention is far beyond current capabilities of most totally automated systems except in rare niche areas such as drug discovery.

\subsection{Dimensions of Smartness}

By the definition above, smartness of an object, totally automated system, or sociotechnical system is best described as a set of dimensions that are continuous variables going from not at all smart to somewhat smart to extremely smart. Tables 2, 3, 4, and 5 provide an initial description the "somewhat" and "extreme" parts of those dimensions. As will be illustrated in the next section, the dimensions in those tables might be used as an aid for thinking about different ways to make an object or system smarter or less smart, either of which might be more advantageous for specific purposes and/or specific stakeholders.

Table 2. Dimensions related to automated information processing in general.

\begin{tabular}{|l|l|l|}
\hline Dimension & \multicolumn{1}{|c|}{ Somewhat smart } & \multicolumn{1}{c|}{ Extremely smart } \\
\hline $\begin{array}{l}\text { Capture } \\
\text { information }\end{array}$ & $\begin{array}{l}\text { Captures predefined data items } \\
\text { using data capture techniques } \\
\text { designed for the data captured }\end{array}$ & $\begin{array}{l}\text { Uses context-related knowledge (not } \\
\text { prespecified knowledge) to decide which } \\
\text { information to capture and how to cap- } \\
\text { ture it }\end{array}$ \\
\hline $\begin{array}{l}\text { Transmit } \\
\text { information }\end{array}$ & $\begin{array}{l}\text { Transmits predefined data items } \\
\text { using transmission techniques } \\
\text { designed for the data transmitted }\end{array}$ & $\begin{array}{l}\text { Uses context-related knowledge (not } \\
\text { prespecified knowledge) to decide where } \\
\text { information needs to be transmitted and } \\
\text { how to transmit it }\end{array}$ \\
\hline $\begin{array}{l}\text { Store in- } \\
\text { formation }\end{array}$ & $\begin{array}{l}\text { Stores predefined information } \\
\text { using data storage techniques } \\
\text { designed for the data stored }\end{array}$ & $\begin{array}{l}\text { Uses context-related knowledge (not } \\
\text { prespecified knowledge) to decide how } \\
\text { and where to store information }\end{array}$ \\
\hline $\begin{array}{l}\text { Retrieve } \\
\text { information }\end{array}$ & $\begin{array}{l}\text { Retrieves predefined data items } \\
\text { using data retrieval techniques } \\
\text { designed for the data retrieved }\end{array}$ & $\begin{array}{l}\text { Uses context-related knowledge (not } \\
\text { prespecified knowledge) to decide how to } \\
\text { find information and how to retrieve it }\end{array}$ \\
\hline $\begin{array}{l}\text { Manipulate } \\
\text { information }\end{array}$ & $\begin{array}{l}\text { Manipulates predefined data } \\
\text { items or aggregations of data } \\
\text { items using data manipulation } \\
\text { techniques designed for the pre- } \\
\text { specified data. }\end{array}$ & $\begin{array}{l}\text { Uses context-related knowledge (not } \\
\text { prespecified knowledge) to decide what } \\
\text { manipulation of information is needed } \\
\text { and how to produce that result }\end{array}$ \\
\hline $\begin{array}{l}\text { Display } \\
\text { information }\end{array}$ & $\begin{array}{l}\text { Displays predefined data items or } \\
\text { aggregations of data items using } \\
\text { data display techniques designed } \\
\text { for the prespecified data }\end{array}$ & $\begin{array}{l}\text { Uses context-related knowledge (not } \\
\text { prespecified knowledge) to decide what } \\
\text { information would be most valuable to } \\
\text { display }\end{array}$ \\
\hline \multicolumn{2}{|l}{}
\end{tabular}

The dimensions in Table 2 are the six aspects of automated information processing [4], i.e., capturing, transmitting, storing, retrieving, manipulating, and displaying information. Most of the smart things listed in this paper's introduction (e.g., smart glasses, smart locks, and smart meters) capture information and then use that infor- 
mation to perform their primary functions. Some of them transmit, store, or retrieve information; some do not. Most of them manipulate information, e.g. performing calculations using the information or changing the format of the information. Many entities are somewhat smart along one or more of the six dimensions. Few are extremely smart along any of those dimensions. Notice Table 2's use of the terms information, data, and knowledge. The first column uses the term information because electronic signals that are processed must be information, i.e., must have some impact in relation to the function at hand. Without such impact, the data collected and transmitted, would be considered data, not information. The second column (somewhat smart) uses the term data because the physical processing occurs through applying predefined techniques to predefined data items. The fourth column (extremely smart) uses the term knowledge because extremely smart implies a higher order of purpose and semantic mastery than is implied by merely processing data.

Table 3 presents dimensions related to internal regulation, which is increasingly important as objects and systems become more automated and more autonomous. Each dimension relies on information processing and each overlaps to some extent with some of the dimensions in other categories. The five dimensions are based largely on the description of smart service system in [1].

Table 3. Dimensions related to internal regulation

\begin{tabular}{|l|l|l|}
\hline Dimension & \multicolumn{1}{|c|}{ Somewhat smart } & \multicolumn{1}{c|}{ Extremely smart } \\
\hline $\begin{array}{l}\text { Self- detec- } \\
\text { tion }\end{array}$ & $\begin{array}{l}\text { Uses prespecified data and criteria } \\
\text { to characterize its existence as sepa- } \\
\text { rate from but possibly related to the } \\
\text { existence of other relevant entities }\end{array}$ & $\begin{array}{l}\text { Performs non-scripted activities that } \\
\text { establish and maintain its separate } \\
\text { identity within the surrounding ecosys- } \\
\text { tem. }\end{array}$ \\
\hline $\begin{array}{l}\text { Self- } \\
\text { monitoring }\end{array}$ & $\begin{array}{l}\text { Uses predefined sensing techniques, } \\
\text { criteria, and data to monitor its } \\
\text { internal state }\end{array}$ & $\begin{array}{l}\text { Uses non-scripted methods for self- } \\
\text { monitoring in order to maintain the } \\
\text { entity itself }\end{array}$ \\
\hline $\begin{array}{l}\text { Self- } \\
\text { diagnosis }\end{array}$ & $\begin{array}{l}\text { Diagnoses internal problems by } \\
\text { applying predefined techniques and } \\
\text { criteria to predefined data }\end{array}$ & $\begin{array}{l}\text { Diagnoses internal problems by per- } \\
\text { forming novel analysis not scripted in } \\
\text { advance by designers }\end{array}$ \\
\hline $\begin{array}{l}\text { Self - } \\
\text { correction }\end{array}$ & $\begin{array}{l}\text { Uses predefined techniques, criteria, } \\
\text { and data to modify internal parame- } \\
\text { ters or business rules }\end{array}$ & $\begin{array}{l}\text { Uses non-scripted methods for identi- } \\
\text { fying deviations from past, current, or } \\
\text { future goals and determining how to } \\
\text { adjust nor to meet those goals in the } \\
\text { future }\end{array}$ \\
\hline $\begin{array}{l}\text { Self- } \\
\text { organization }\end{array}$ & $\begin{array}{l}\text { Uses predefined techniques, criteria, } \\
\text { and data to organize its own opera- } \\
\text { tional structure }\end{array}$ & $\begin{array}{l}\text { Uses non-scripted methods to organize } \\
\text { different components of the entity in } \\
\text { order to achieve its goals }\end{array}$ \\
\hline
\end{tabular}

The dimensions in Table 4 are related to various aspects of performing action in the world beyond the boundary of the nominally smart object or system. The dimensions in Table 4 involve applying information processing (see Table 2) to systemic purposes including sensing, actuation, coordination, communication, and control, topics from the descrition of smart service system mentioned earlier. The reference to non-scripted methods in the extremely smart column sets the bar very high because it calls for invention using techniques and goals that are determined dynamically based 
on the context at hand. Determining techniques and goals on-the-fly is often challenging for people. Imbuing that level of "smartness" into totally automated systems is far beyond current capabilities except possibly in certain niche situations.

Table 4. Dimensions related to action in the world

\begin{tabular}{|l|l|l|}
\hline \multicolumn{1}{|c|}{ Dimension } & \multicolumn{1}{|c|}{ Somewhat smart } & \multicolumn{1}{c|}{ Extremely smart } \\
\hline Sensing & $\begin{array}{l}\text { Captures predefined data items } \\
\text { using sensing techniques designed } \\
\text { for the types of data that are sensed }\end{array}$ & $\begin{array}{l}\text { Uses non-scripted methods to } \\
\text { decide how to sense situations or } \\
\text { other higher order information } \\
\text { (e.g., work being done in a way } \\
\text { that is not competent) }\end{array}$ \\
\hline Actuation & $\begin{array}{l}\text { Uses predefined methods and } \\
\text { information to actuate activity } \\
\text { involved in primary functions }\end{array}$ & $\begin{array}{l}\text { Uses non-scripted methods for } \\
\text { deciding what to actuate and how } \\
\text { to perform the actuation. }\end{array}$ \\
\hline Coordination & $\begin{array}{l}\text { Uses predefined business rules or } \\
\text { decision tables to support coordi- } \\
\text { nation of actors and/or uses of } \\
\text { resources }\end{array}$ & $\begin{array}{l}\text { Uses non-scripted methods for } \\
\text { deciding what needs to be coordi- } \\
\text { nated and how to perform the co- } \\
\text { ordination }\end{array}$ \\
\hline Communication & $\begin{array}{l}\text { Uses predefined methods and rules } \\
\text { for communicating with people or } \\
\text { supporting human communication }\end{array}$ & $\begin{array}{l}\text { Uses non-scripted methods for } \\
\text { identifying communication recipi- } \\
\text { ents and deciding what needs to be } \\
\text { communicated and how to perform } \\
\text { the communication effectively }\end{array}$ \\
\hline Control & $\begin{array}{l}\text { Manipulates predefined data items } \\
\text { or aggregations of data items using } \\
\text { data manipulation techniques de- } \\
\text { signed for the prespecified data. }\end{array}$ & $\begin{array}{l}\text { Uses non-scripted methods for } \\
\text { deciding what needs to be con- } \\
\text { trolled and how to perform the } \\
\text { control activities effectively }\end{array}$ \\
\hline
\end{tabular}

Table 5 presents six dimensions related to knowledge acquisition. This dimension starts with sensing or discovering predefined data items. From there it moves to classifying and compiling data in a way that constitutes factual knowledge. More advanced dimensions involve inferring or extrapolating from examples, from statistical summaries, or from abstractions, and at some point testing and evaluating the knowledge acquired. 
Table 5. Dimensions related to knowledge acquisition

\begin{tabular}{|c|c|c|}
\hline Dimension & Somewhat smart & Extremely smart \\
\hline $\begin{array}{l}\text { Sensing or } \\
\text { discovering }\end{array}$ & $\begin{array}{l}\text { Uses predefined scripts to cap- } \\
\text { ture predefined data items }\end{array}$ & $\begin{array}{l}\text { Uses context-related knowledge (not } \\
\text { prespecified knowledge) to decide } \\
\text { which information to capture and how } \\
\text { to capture it }\end{array}$ \\
\hline Classifying & $\begin{array}{l}\text { Uses predefined scripts to classi- } \\
\text { fy information }\end{array}$ & $\begin{array}{l}\text { Uses context-related knowledge to } \\
\text { decide how to classify information }\end{array}$ \\
\hline Compiling & $\begin{array}{l}\text { Uses predefined scripts to com- } \\
\text { pile information }\end{array}$ & $\begin{array}{l}\text { Uses context-related knowledge to } \\
\text { decide how to compile information to } \\
\text { make it as useful as possible }\end{array}$ \\
\hline $\begin{array}{l}\text { Inferring or } \\
\text { extrapolating } \\
\text { from examples } \\
\text { or statistical } \\
\text { summaries } \\
\end{array}$ & $\begin{array}{l}\text { Uses predefined scripts to infer } \\
\text { or extrapolate conclusions from } \\
\text { concrete examples or statistical } \\
\text { summaries of examples }\end{array}$ & $\begin{array}{l}\text { Uses knowledge that is not specified in } \\
\text { the form of a script to infer or extrapo- } \\
\text { late conclusions from concrete exam- } \\
\text { ples or statistical summaries of exam- } \\
\text { ples }\end{array}$ \\
\hline $\begin{array}{l}\text { Inferring or } \\
\text { extrapolating } \\
\text { from abstrac- } \\
\text { tions }\end{array}$ & $\begin{array}{l}\text { Uses predefined scripts to infer } \\
\text { or extrapolate conclusions from } \\
\text { abstractions }\end{array}$ & $\begin{array}{l}\text { Uses knowledge that is not specified in } \\
\text { the form of a script to infer or extrapo- } \\
\text { late conclusions from abstractions }\end{array}$ \\
\hline $\begin{array}{l}\text { Testing and } \\
\text { evaluating }\end{array}$ & $\begin{array}{l}\text { Uses predefined scripts to test or } \\
\text { evaluate hypothesized } \\
\text { knowledge }\end{array}$ & $\begin{array}{l}\text { Uses knowledge not in the form of a } \\
\text { script to test or evaluate hypothesized } \\
\text { knowledge }\end{array}$ \\
\hline
\end{tabular}

\section{Using the Dimensions of Smartness for Describing, Analyzing, or Designing Objects or Systems}

A test of whether the dimensions of smartness are useful is to apply them for describing, analyzing, or designing smartness into objects or systems. Lacking an empirical test at the time of this writing, the applicability of the dimensions is illustrated by using two hypothetical examples, an imagined smart water bottle (a smart object) and an imagined attempt to make a hiring system smarter.

\subsection{Use Related to a Potentially Smart Object, a Water Bottle}

Imagine that a company's R\&D department uses Tables 2, 3, 4, and 5 to brainstorm about different forms of smartness that might apply to product X, a smart version of the type of water bottle that some people carry around and use when exercising.

Smartness dimensions related to information processing. With the necessary electronics, X could capture information related to the amount of water in the bottle, the amount drunk each time the bottle is used, the temperature of the water, and even characteristics of the user such as identity, temperature, or pulse rate. The data could be stored and retrieved. It could be transmitted wirelessly to a phone or other device could be manipulated and displayed in graphs by using a related app.

Smartness dimensions related to internal regulation. With self-monitoring, $\mathrm{X}$ could track the rate at which water was consumed. It might monitor the temperature 
of the water and even the presence of impurities. It might self-diagnose problems, such as inadequate or excessive rate of usage or presence of impurities. X might selfcorrect, if it had a way of heating, cooling, or filtering the water.

Smartness dimensions related to action in the world. X's tracking data from its sensing capabilities might be used actuate a visual signal that communicates the user's need to drink water or the fact that the water supply was impure or almost depleted. It also might communicate with a phone or fitness tracker. $\mathrm{X}$ might tighten its opening to exert control to prevent the user from drinking too rapidly.

Smartness dimensions related to knowledge acquisition. $\mathrm{X}$ could sense data and then classify it in relation to the types of issues revealed. It would compile a history of usage including time, place, quantity, and other characteristics of each instance of usage. Inference or extrapolation from the compiled information could generate statistical knowledge about usage patterns for individuals and populations, plus details of individual or group idiosyncrasies.

I imagined the hypothetical water bottle example as a simple if unlikely illustration of how to use the smartness dimensions. Later I performed a search on "smart water bottle" and found not only product examples, but product reviews that mentioned smart capabilities but seemed to focus more on cost and features.

\subsection{Use Related to a Sociotechnical System, a Hiring System}

Imagine that managers of a technology company wanted to explore whether their hiring system might benefit from greater smartness. They know that their employees are smart and believe that their processes make sense. Nonetheless, they wonder whether a smarter hiring system would reduce costs and improve hiring results.

Smartness dimensions related to information processing. Their current system contains technology that seems to process information adequately. It captures necessary information, stores it in a database where it is retrieved easily, provides a straightforward way of manipulating information to generate management reports, and displays the information in convenient forms. Table 2's descriptions of extremely smart information processing seem like science fiction to the managers.

Smartness dimensions related to internal regulation. Looking at internal regulation highlights important problems in the system, which cannot be viewed as selfmonitoring, self-diagnosing, or self-correcting. In some ways it seems selforganizing, but the CEO views that as a synonym of excessively improvisational. The CEO believes the system needs smarter management rather than smarter technology.

Smartness dimensions related to action in the world. They see room for improvement in sensing the ability of applicants to work with others. Perhaps video or some other technology might help in detecting antisocial tendencies in applicants. Smarter actuation might produce a path for interviewing the most qualified applicants sooner. Smarter coordination might call for better scheduling of interviews. The communication dimension might lead to wondering whether more interviews could be done by video and whether interviewers could submit their comments by video. Smarter control of the process might involve better notifications of due dates and better feedback related to interview reports. 
Smartness dimensions related to knowledge acquisition. Management believes that knowledge acquisition is not a significant problem. The sensing, classification, and compilation of knowledge about hiring seems adequate. They question whether knowledge from smarter inferences or extrapolations related to examples or abstractions would make any difference. They like the idea of testing or evaluating the company knowledge about specific interviewees, but they do not know how that might be done in a smarter way.

\section{Conclusion}

This paper presented principles related to smartness, defined smart, presented dimensions related to four categories of smartness, and used two brief examples to show how those dimensions might be used in thinking about how to make an object or system smarter. I believe that serious discussion of smart living, working, and organizing requires clarity about the topic, i.e., a definition of smart and a related series of dimensions such as those presented here. Obviously, other definitions and sets of dimensions might be proposed. Ideally, alternative perspectives on smartness should be tested in situations related to the adoption of smart things.

When and how is it wise to use smart technologies? This paper's length limitations dictated that it could not explore important topics related to the social benefits, costs, and implications of using smart technologies. Many examples show that the use of smart technologies may or may not be beneficial to direct users of those technologies and to many other stakeholders concerned with topics ranging from privacy and surveillance through employment, equity, and wealth.

Consider just several types of impacts of just one type of smart device: Reports in the Spine Journal [5] and in other sources have described "text neck" as a medical issue related to the stress on neck and postural muscles due to flexing the neck for extended time spans to look downward at smart phones. Texting on smart phones is associated with a substantial percentage of car crashes [6]. The social scientist Sherry Turkle "found that children now compete with their parents' devices for attention, resulting in a generation afraid of the spontaneity of a phone call or face-to-face interaction." [7]. From a different perspective, "Facebook's former president, Sean Parker, recently said the platform was designed to be addictive and to 'consume as much of your time and conscious attention as possible. .... It literally changes your relationship with society, with each other ... God only knows what it's doing to our children's brains'." [7]. Impacts of other smart objects and systems could be discussed as well, with the range of topics including "surveillance capitalism" [8], algorithmic justice [9]. dangers of smart drones [10], and sometimes making everyday life more complicated and less convenient [11] .

In summary, defining smartness and exploring its various aspects is one of the ways to add care and specificity to discussions of how technical developments have had major consequences to date and that likely will bring many positive and negative impacts on living, working, and organizing in the future. 


\section{References}

1. Medina-Borja, A.: Editorial column—smart things as service providers: a call for convergence of disciplines to build a research agenda for the service systems of the future. Service Science, 7(1), ii-v (2015).

2. Simon H.A.: The sciences of the artificial. MIT Press (1996).

3. Alter, S.: Theory of workarounds, (2014).

4. Alter, S. : The work system method: Connecting people, processes, and IT for business results. Larkspur, CA: Work System Press (2006).

5. Cuéllar, J.M., Lanman, T.H. : "Text neck": an epidemic of the modern era of cell phones?. The Spine Journal, 17(6), 901-2 (2017).

6. Gliklich, E., Guo, R., Bergmark, R.W. : Texting while driving: A study of 1211 US adults with the distracted driving survey. Preventive medicine reports, 4, 486-489, (2016).

7. Popescu, A.: Keep your head up: How smartphone addiction kills manners and moods, New York Times, (Jan. 25, 2018).

8. Zuboff S. : Big other: surveillance capitalism and the prospects of an information civilization. Journal of Information Technology, 30(1),75-89, (2015).

9. Koene A. : Algorithmic bias: Addressing growing concerns, IEEE Technology and Society Magazine, 36(2):31-32 (2017)

10. ABC7News: UC Berkeley professor helps create viral video to warn about killer robots, (Nov. 17, 2017). viewed at http://abc7news.com/technology/uc-berkeley-professor-helpscreate-viral-video-to-warn-about-killer-robots/2664980/

11. Chen, B. X. : In an era of 'smart' things, sometimes dumb stuff is better, New York Times, (Feb. 21, 2018). 